\title{
KRAFT PULPING PROPERTIES OF EUROPEAN BLACK PINE CONE
}

\author{
Sezgin Koray Gulsoy ${ }^{1, \wedge}$, Fatih Ozturk ${ }^{1}$
}

\begin{abstract}
In this study, different mixtures of cones and wood chips of European black pine (Pinus nigra) were kraft cooked, and the resulting pulp and paper properties were investigated. Also, the chemical compositions and fiber dimensions of the cones and wood were examined. Cone chips were mixed in different ratios $(5 \%, 10 \%, 15 \%$, and $20 \%)$ with wood chips prior to pulping. Also, kraft pulping of $100 \%$ cone chips and $100 \%$ wood chips were conducted so the results could be compared. The kraft pulp of $100 \%$ cone chips had lower pulp yield, lower pulp strength, and higher kappa number than that of $100 \%$ wood chips. As the ratio of cone chips was increased in the mixture of cone chips and wood chips, higher kappa numbers and lower total screened yield were obtained. Additionally, the strength properties and brightness of the resulting kraft pulp were decreased gradually. However, the opacity of the pulp was increased slightly. Consequently, cone fibers of European black pine can be used as a raw material in the paper industry by mixing with wood fibers.
\end{abstract}

Keywords: Burst index, chemical composition, fiber dimensions, holocellulose, Kappa number, Klason lignin, paper properties, Pinus nigra, tear index, tensile index.

\section{INTRODUCTION}

European black pine (Pinus nigra) is spread over more than 3,5 million hectares from western North Africa through southern Europe to Asia Minor (Isajev et al. 2004). Pinus nigra has highly productive mast years that occur every three to five years (Kerr 2000). These trees produce an average of 33 cones in low cone-production years and 757 cones in mast years (Boulant et al. 2009).

Cones, which are the reproductive organs of coniferous species, are considered as a forest residue, and, over time, they become mixed with the soil on the floor of the forest. To date, no technological uses have been identified for the cones' fibers. Recently, cones from stone pine trees were evaluated by Buyuksari et al. 2010 and Ayrilmis et al. 2009, for their potential use in particleboard and medium density fiberboard (MDF). In addition, some studies on the chemical compositions of various types of cones have been reported by several researchers (Dönmez et al. 2012, Eberhardt and Young 1996, Ganenko et al. 2006, Gonultas and Ucar 2013, Hafizoglu and Reunanen 1994, Kilic et al. 2011, Macchioni et al. 2003, Micales et al. 1994, Norin and Winell 1971, Ohtsu et al. 2000, Ucar and Ucar 2008, Yang et al. 2005, 2010). However, no reports have been published on the use of cones in the paper industry either alone or mixed with wood. Thus, the aim of this study was to investigate the effects of different mixtures of cones and wood chips from European black pine (Pinus nigra) on the properties of the resulting pulp and paper. Also, we determined the chemical composition and morphology of fibers from European black pine cones and evaluated the usability of the fibers in the paper industry.

\footnotetext{
${ }^{1}$ Department of Forest Product Engineering, Faculty of Forestry, Bartin University. Bartin, Turkey.

^ Corresponding author: sgulsoy@bartin.edu.tr

Received: 18.12.2014 Accepted: 28.07.2015
} 


\section{MATERIAL AND METHODS}

\section{Sample Preparation}

The wood samples and open-cone (not fresh) samples of European black pine (Pinus nigra Arnold) that were used in this study were taken from the Bartin Province in Turkey. The cone samples were randomly collected from forest area. The average weight, length, and width of the open-cone samples were $19,66 \mathrm{~g} ; 6,61 \mathrm{~cm}$; and $6,43 \mathrm{~cm}$; respectively. The wood samples were chipped manually to $25 \times 15 \times 5$ $\mathrm{mm}$ size for pulping. The open-cone samples were divided vertically into 8-12 pieces, according to the sizes of the cones, for pulping. Then, the wood and cone chips were air-dried and stored in dry conditions.

\section{Chemical Analysis}

The wood and cone samples were prepared for chemical analysis according to the TAPPI T 257 standard. The holocellulose (Wise and Karl 1962), $\alpha$-cellulose (TAPPI T 203), and klason lignin (TAPPI $\mathrm{T}$ 222) contents of the samples were determined according to the relevant methods. The solubility properties were determined based on the alcohol (TAPPI T 204), cold-hot water (TAPPI T 207), and $1 \% \mathrm{NaOH}$ (TAPPI T 212) methods.

\section{Fiber Dimensions}

The wood and cone samples were macerated using the chlorite method (Spearin and Isenberg 1947). Individual fibers were obtained by agitating the samples after maceration (Berlyn and Miksche 1976). The samples were dehydrated with ethyl alcohol and stored in glycerin. The dimensions of 100 randomly-selected fibers were determined. Also, the slenderness ratio (fiber length/fiber width), the Runkel ratio [( $\times$ cell-wall thickness $) /$ lumen width], and flexibility ratio [(lumen width/fiber width $) \times$ 100] were calculated.

\section{Kraft Pulping and Pulp Properties}

In this study, six kraft cooks were conducted using various wood chip:cone chip ratios (100:0, 95:5, 90:10, 85:15, 80:20 and 0:100). Kraft pulping for each of the mixtures with different chip ratios was conducted using a laboratory-scale, cylindrical-type, rotary digester. In each pulping experiment, $700 \mathrm{~g}$ of oven-dried chips were cooked. Table 1 provides the cooking conditions that were used in this study. After cooking, the pulp samples were washed to remove the black liquor and then disintegrated in a laboratory-type pulp mixer. The disintegrated pulp samples were screened using a Somerville-type pulp screen (TAPPI T 275).

Table 1. Kraft pulping conditions of cone and wood of European black pine.

\begin{tabular}{lc}
\hline Active alkali $(\%)$ & 24 \\
Sulfidity $(\%)$ & 30 \\
Liquor/wood ratio & $4 / 1$ \\
Cooking temperature $\left({ }^{\circ} \mathrm{C}\right)$ & 170 \\
Time to cooking temperature (min.) & 90 \\
Time at cooking temperature (min.) & 60 \\
\hline
\end{tabular}

Kappa number (TAPPI T 236), screened yield (TAPPI T 210), viscosity (SCAN-CM 15-62), and were determined according to relevant methods. Kappa number is an indirect measurement of lignin content: \% lignin content $=0,15 \mathrm{x}$ kappa number. 


\section{Handsheet Properties}

The pulps were then beaten to $25^{\circ} \mathrm{SR}$ in a Valley Beater according to TAPPI T 200. Freeness of pulps was determined according to ISO 5267-1. Handsheets $\left(75 \mathrm{~g} / \mathrm{m}^{2}\right)$ were obtained from the pulps using a Rapid-Kothen Sheet Former (ISO 5269-2). In accordance with TAPPI T 402, the handsheets were kept overnight in a conditioning room before testing. The tensile index and tensile energy absorption (TEA) (TAPPI T 494), burst index (TAPPI T 403), tear index (TAPPI T 414), brightness (TAPPI T 525), and opacity (TAPPI T 519) of the handsheets were measured using the relevant TAPPI standard methods.

\section{Statistical Analysis}

An independent $t$-test was used to determine whether there was any significant difference $(\mathrm{P}<0,05)$ in chemical composition and fiber morphology between the wood and cone samples. The data of the handsheet properties for each chip ratio were analyzed statistically using ANOVA and Tukey's test at the $95 \%$ confidence level. In the tables and figures, the different letter on the same line denotes that the difference in the mean values of the properties among the compared groups was statistically significant $(\mathrm{P}<0,05)$. All statistical analyses were performed using SPSS version 16.0.

\section{RESULTS AND DISCUSSION}

\section{Chemical Composition}

There was a statistically-significant difference between the chemical compositions of the wood and the cones from European black pine trees (Table 2). The holocellulose and $\alpha$-cellulose content of the cones were less than those of the wood. However, klason lignin and solubility values in hot and cold water, in a $1 \% \mathrm{NaOH}$ solution, and in alcohol were greater than those of the wood.

Klason lignin, hot water, and $1 \% \mathrm{NaOH}$ solubilities of old cones from black pine trees were determined to be $38,6 \% ; 5,9 \%$ and $19,9 \%$; respectively, by Ucar and Ucar 2008. Dönmez et al. 2012, reported that the holocellulose, $\alpha$-cellulose, and klason lignin contents of fresh cones from black pine trees were 63,54\%; 27,99\% and 31,70\% respectively. Also Dönmez et al. 2012, found the solubilities of fresh cones from Pinus nigra trees in alcohol, hot and cold water, and 1\% $\mathrm{NaOH}$ to $12,18 \% ; 7,35 \%$; $5,40 \%$ and $17,93 \%$; respectively.

Table 2. Chemical composition of wood and cone of European black pine.

\begin{tabular}{lcc}
\hline Experiment & Wood & Cone \\
\hline Holocellulose (\%) & $69,66 \pm 0,19 \mathrm{a}$ & $61,45 \pm 0,65 \mathrm{~b}$ \\
$\alpha$-cellulose (\%) & $47,87 \pm 0,57 \mathrm{a}$ & $38,73 \pm 0,29 \mathrm{~b}$ \\
Klason lignin (\%) & $26,35 \pm 0,86 \mathrm{a}$ & $31,33 \pm 0,83 \mathrm{~b}$ \\
$1 \%$ NaOH solubility (\%) & $11,17 \pm 0,07 \mathrm{a}$ & $20,07 \pm 0,19 \mathrm{~b}$ \\
Hot water solubility (\%) & $2,43 \pm 0,12 \mathrm{a}$ & $4,34 \pm 0,18 \mathrm{~b}$ \\
Cold water solubility (\%) & $1,28 \pm 0,04 \mathrm{a}$ & $3,31 \pm 0,13 \mathrm{~b}$ \\
Alcohol solubility (\%) & $4,40 \pm 0,15 \mathrm{a}$ & $6,68 \pm 0,23 \mathrm{~b}$ \\
\hline
\end{tabular}




\section{Fiber Dimensions}

A statistically significant difference was observed between the dimensions of wood fibers and the cone fibers from European black pine trees (Table 3). The wood fibers were longer and wider than the cone fibers. Also, the wood fibers had wider lumen and thicker cell walls than the cone fibers. In addition, the wood fibers had higher slenderness ratio, Runkel ratio, and flexibility ratio than the cone fibers.

Table 3. Fiber dimensions of wood and cone of European black pine.

\begin{tabular}{lcc}
\hline Experiment & Wood & Cone \\
\hline Fiber length $(\mathrm{mm})$ & $3,01 \pm 0,65 \mathrm{a}$ & $1,25 \pm 0,21 \mathrm{~b}$ \\
Fiber width $(\mu \mathrm{m})$ & $46,40 \pm 5,54 \mathrm{a}$ & $31,10 \pm 4,68 \mathrm{~b}$ \\
Lumen width $(\mu \mathrm{m})$ & $23,40 \pm 3,22 \mathrm{a}$ & $13,70 \pm 2,81 \mathrm{~b}$ \\
Cell wall thickness $(\mu \mathrm{m})$ & $11,50 \pm 1,90 \mathrm{a}$ & $8,70 \pm 1,42 \mathrm{~b}$ \\
Fiber flexibility & 50,43 & 44,05 \\
Slenderness ratio & 64,87 & 40,19 \\
Runkel ratio & 0,98 & 0,56 \\
\hline
\end{tabular}

\section{Pulp and Paper Properties}

Table 4 presents the kraft pulp properties of mixtures of wood chips and cone chips from European black pine trees. The screened and total yields of kraft pulp from the wood were greater than those from the cones. However, the kappa number of the kraft pulp using wood was less than that of the kraft pulp using the cones. As the proportion of cone chips increased in the wood-cone mixture, pulping resulted in a higher kappa number and lower total and screened yields. These results could be explained by the fact that the wood chips had higher $\alpha$-cellulose content and lower lignin content than the cone chips (Table 2 ). The $100 \%$ cone pulp viscosity was lower than that of $100 \%$ wood pulp. In addition, viscosity of pulps was decreased with increasing cone ratio in mixtures.

Table 4. The kraft pulp properties of wood and cone chip mixtures of European black pine.

\begin{tabular}{ccccccc}
\hline $\begin{array}{c}\text { Cone:Wood } \\
\text { ratio }\end{array}$ & $\begin{array}{c}\text { Screened } \\
\text { Yield } \\
\mathbf{( \% )}\end{array}$ & $\begin{array}{c}\text { Reject } \\
\mathbf{( \% )}\end{array}$ & $\begin{array}{c}\text { Total } \\
\text { Yield } \\
\mathbf{( \% )}\end{array}$ & $\begin{array}{c}\text { Kappa } \\
\text { Number }\end{array}$ & $\begin{array}{c}\text { Lignin } \\
\text { content } \mathbf{( \% )}\end{array}$ & $\begin{array}{c}\text { Viscosity } \\
\left(\mathbf{c m}^{\mathbf{3}} \mathbf{g}\right)\end{array}$ \\
\hline $0 / 100$ & 43,0 & 0,5 & 43,5 & 24,1 & 3,6 & 1241,0 \\
$5 / 95$ & 42,3 & 0,2 & 42,5 & 24,8 & 3,7 & 1211,4 \\
$10 / 90$ & 42,2 & 0,5 & 42,7 & 27,3 & 4,1 & 1188,6 \\
$15 / 85$ & 39,7 & 0,5 & 40,2 & 29,6 & 4,4 & 1166,6 \\
$20 / 80$ & 39,1 & 0,4 & 39,5 & 30,7 & 4,6 & 1131,4 \\
$100 / 0$ & 23,1 & 0,3 & 23,4 & 39,1 & 5,9 & 922,1 \\
\hline
\end{tabular}


The strength properties of kraft pulp made from $100 \%$ cone chips were lower than those of the kraft pulp made from 100\% wood chips. The tensile index and TEA of the handsheets decreased as the proportion of cone chips in the cone-wood mixtures increased (Figure 1). When the cone chips comprised $5 \%, 10 \%, 15 \%$, and $20 \%$ of the mixture, the tensile index of handsheets was decreased by about $6 \%, 7 \%$, $11 \%$, and $13 \%$, respectively. When the cone chips made up 5\%,10\%,15\%, and $20 \%$ of the cone-wood chip mixtures, the TEA values of handsheets were decreased about $8 \%, 9 \%, 10 \%$, and $13 \%$, respectively. These results could be attributed to shorter fibers and lower flexibility of cone fibers compared to wood fibers. Tensile index and TEA depends on the length and flexibility of the fibers (Nazhad 2005).

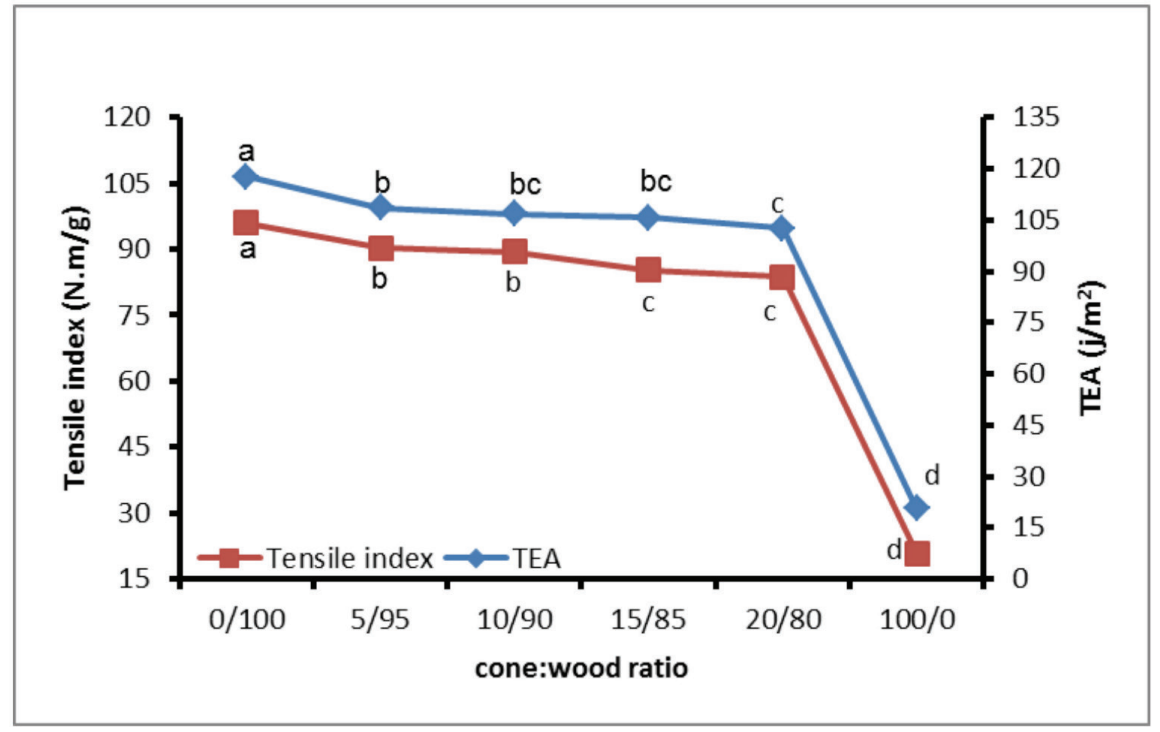

Figure 1. The effect of cone:wood ratio on tensile index and TEA of handsheets.

The burst and tear indices of the handsheets decreased as the cone chip addition ratio increased (Figure 2). Cone chip additions of $5 \%, 10 \%, 15 \%$, and $20 \%$ resulted in decreases in the burst index of about $4 \%$; $4,5 \% ; 7 \%$; and $11 \%$, respectively. The burst index depends on the bonding ability of the fibers (Horn 1978). More flexible fibers produce large contact areas for fiber-to-fiber bonding. Thus, the decreases in the burst index as the cone-chip addition increased could be explained by the cone fibers' having less flexibility than the wood fibers. However, cone chip additions of $5 \%, 10 \%, 15 \%$, and $20 \%$ resulted in the tear index of the handsheets being decreased by about $8 \% ; 9,6 \% ; 17 \%$ and $19 \%$, respectively. Tear index depends on the length of the fibers (Tschirner et al. 2003). Thus, the percentage decreases in the tear index as the addition of cone chips increased could be attributed to the cones having shorter fibers than the wood. 


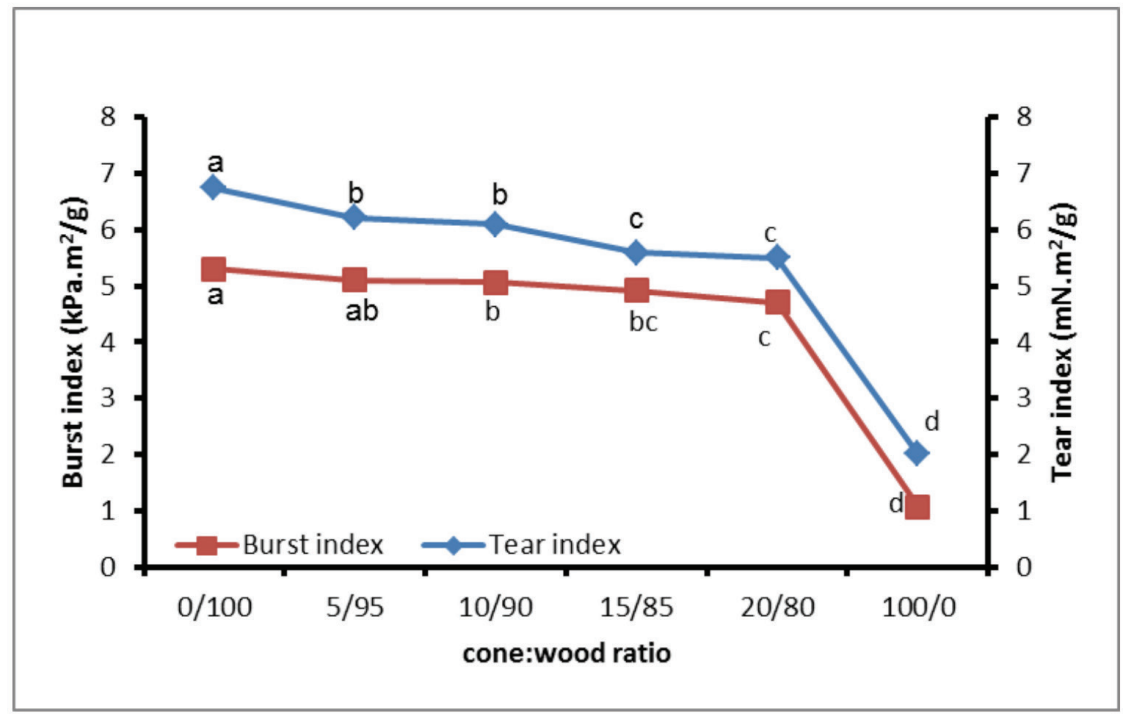

Figure 2. The effect of cone:wood ratio on burst and tear index of handsheets.

The brightness of the handsheets decreased gradually as the cone-chip addition ratio increased, but opacity increased slightly (Figure 3 ). The addition of cone chips so that they made up 5\%,10\%, 15\%, and $20 \%$ of the cone-wood mixture resulted in decreases in brightness of about $6 \% ; 13 \%, 14 \%$ and $22 \%$ respectively. This finding could be explained by the fact that the cone pulp had a higher kappa number than the wood pulp. On the other hand, the linear correlation between handsheet opacity and cone chip ratio in mixtures could be ascribed to negative correlation between handsheet strength properties and opacity (Gurnagul 1995, Talaeipoor and Imani 2008).

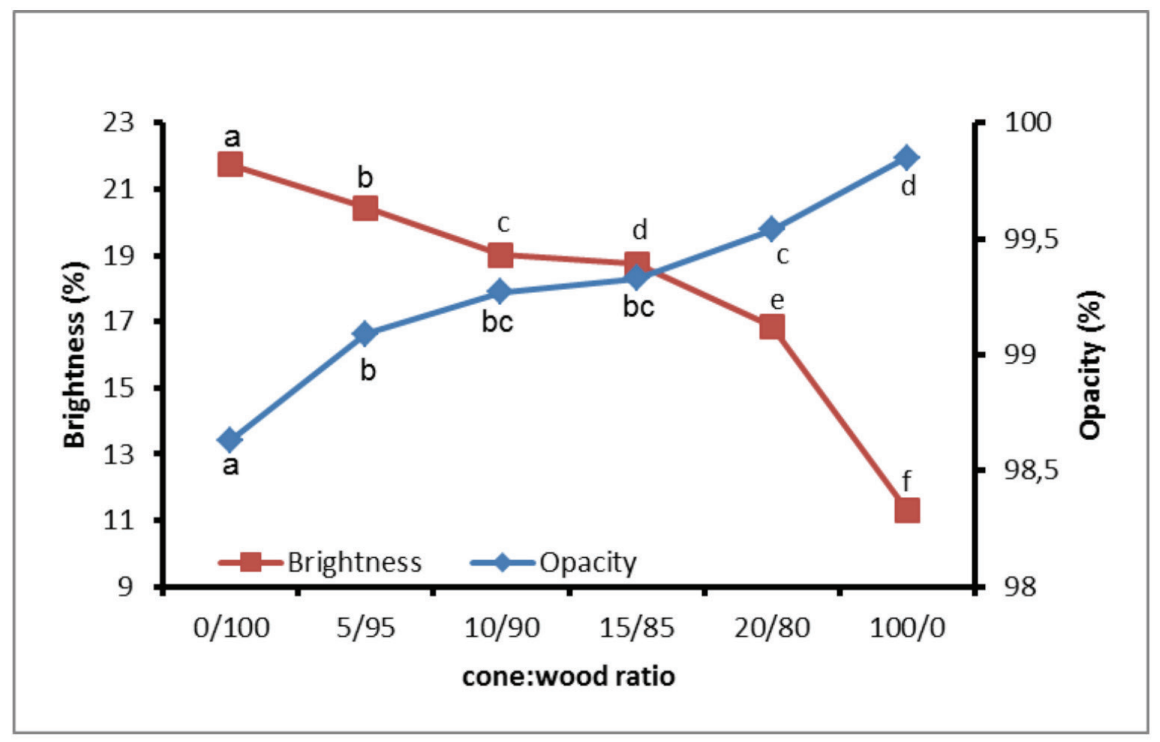

Figure 3. The effect of cone:wood ratio on brightness and opacity of handsheets. 


\section{CONCLUSIONS}

The results of this study showed that the chemical compositions and the dimensions of the fibers of the wood and cones from European black pine trees were different, and the differences were statistically significantly. The cones had lower holocellulose and $\alpha$-cellulose content and greater lignin content than the wood. Also, the wood fibers were longer and wider than the cone fibers. The kraft pulp of $100 \%$ cone chips had lower pulp yield, lower pulp strength, and higher kappa number than that of $100 \%$ wood chips. The strength properties and brightness of the mixture pulps gradually decreased as the cone chip addition ratio increased. The highest pulp strength loss, i.e., about 19\% decrease in the tear index, was observed with the $20 \%$ cone addition. The cones of European black pine can be collected from ground or obtained from harvesting residues. The cone fibers can be used as a raw material in the paper industry by mixing with wood fibers. As a suggestion, the pulping properties of the cones of other softwood species must be investigated with different pulping methods in further studies. Also, a special chipper design can be carried out for cones. Thus, new usage areas for the cones could provide additional income for forest landowners.

\section{REFERENCES}

Ayrilmis, N.; Buyuksari, U.; Avci, E., Koc, E.; 2009. Utilization of pine (Pinus pinea L.) cone in manufacture of wood based composite. Forest Ecol Manag 259: 65-70.

Berlyn, G.P.; Miksche, J.P. 1976. Botanical Microtechnique and Cytochemistry, Iowa State University Press, Ames, IA.

Boulant, N.; Garnier, A.; Curt, T.; Lepart, J. 2009. Disentangling the effects of land use, shrub cover and climate on the invasion speed of native and introduced pines in grasslands. Divers Distrib 15: 1047-1059.

Buyuksari, U.; Avci, E.; Ayrilmis, N.; Akkilic, H. 2010. Effect of pine cone ratio on the wettability and surface roughness of particleboard. Bioresources 5: 1824-1833.

Dönmez, I. E.; Hafizoğlu, H.; Kilic, A.; Tümen, I.; Sivrikaya, H. 2012. Chemical composition of fourteen different coniferous species cones growing naturally in Turkey. Wood Res 57: 339-344.

Eberhardt, T.L.; Young, R.A. 1996. Characterization of conifer seed cone polysaccharides and lignin. Holzforschung 50: 401-407.

Ganenko, T.V.; Khamidullina, E.A.; Medvedeva, S.A. 2006. Chemistry of Pinus sylvestris cones," Chem Nat Compd 42: 612-612.

Gonultas, O.; Ucar, M.B. 2013. Chemical characteristics of the cone and wood of Pinus pinea. Lignocellulose 2: 262-269.

Gurnagul, N. 1995. Sodium hydroxide addition during recycling: effects on fiber swelling and sheet strength. Tappi J 78: 119-124.

Hafizoğlu H.; Reunanen, M. 1994. Composition of oleoresins from bark and cones of Abies nordmanniana and Picea orientalis. Holzforschung 48: 7-11.

Horn, R.A. 1978. Morphology of Pulp Fiber from Hardwoods and Influence on Paper Strength, USDA Forest Service Research Paper FPL 312, Forest Products Laboratory, Madison, WI, USA. 
Isajev, V.; Fady, B.; Semerci, H.; Andonovski, V. 2004. European Black Pine Pinus nigra, International Plant Genetic Resources Institute, Rome.

Kerr, G. 2000. Natural regeneration of Corsican pine (Pinus nigra subsp laricio) in Great Britain. Forestry 73: 479-488.

Kilic, A.; Hafizoglu, H.; Dönmez, I.E.; Tümen, I.; Sivrikaya, H.; Reunanen, M.; Hemming, J. 2011. Extractives in the cones of Pinus species. Eur J Wood Wood Prod 69: 37-40.

Macchioni, F.; Cioni, P.L.; Flamini, G.; Morelli, I.; Maccioni, S.; Ansaldi, M. 2003. Chemical composition of essential oils from needles, branches, and cones of Pinus pinea, P. halepensis, P. pinaster, and P. nigra from central Italy. Flavour Fragr J 18: 139-143.

Micales, J.A.; Han, J.S.; Davis, J.L.; Joung, R.A. 1994. Chemical composition and fungitoxic activities of pine cone extractives. Biodeterior Res 4: 317-332.

Nazhad, M.M. 2005. Recycled fiber quality - A review. J Ind Eng Chem 11: 314-329.

Norin, T.; Winell, B. 1971. Diterpenoids of cones from two Cedrus species. Phytochemistry 10: 2818-2821.

Ohtsu, H.; Tanaka, R.; In, Y.; Matsunaga, S.; Tokuda, H.; Nishino, H. 2000. New abietane diterpenoids from the cones of Larix kaempferi. Can J Chem 78: 31-40.

Spearin, W.E.; Isenberg, I. H. 1947. Maceration of woody tissue with acetic acid and sodium chlorite. Science 105: 214-214.

Talaeipoor, M.; Imani, R. 2008. Effect of debonding agents and refining on the properties of deinked pulp. Tappi J 9: 12-14.

Tschirner, U.; Ramaswamy, S.; Goel, A. 2003. Effect of cereal straw fibre addition to papermaking furnish. Pulp Pap Canada 104: 26-29.

Ucar, M.B.; Ucar, G. 2008. Lipophilic extractives and main components of black pine cones. Chem Nat Compd 44: 380-383.

Wise, L.E.; Karl, H.L. 1962. Cellulose and Hemicellulose in Pulp and Paper Science and Technology, McGraw Hill Book Co, New York.

Yang, X.; Ding, Y.; Zhang, D.M.; Sun, Z.H. 2005. Studies on chemical constituents from pine cone of Pinus armandii. China J Chinese Mater Med 30: 518-520.

Yang, X.; Zhang, H.; Zhang, Y.; Zhao, H.; Dong, A.; Xu, D.; Yang, L.; Ma, Y.; Wang, J. 2010. Analysis of the essential oils of pine cones of Pinus koraiensis Steb. Et Zucc. and P. sylvestris L. from China. $J$ Essent Oil Res 22: 446-448. 